\title{
The potential use of probiotic and beneficial bacteria in the Brazilian dairy industry
}

\author{
Monique Colombo ${ }^{1}$, Svetoslav Dimitrov Todorov ${ }^{1,2}$, Monique Eller ${ }^{3}$ and Luís Augusto Nero ${ }^{1 *}$ \\ 'Departamento de Veterinária, Universidade Federal de Viçosa, Viçosa, MG, Brazil \\ ${ }^{2}$ Faculdade de Ciências Farmacêuticas, Universidade de São Paulo, São Paulo, SP, Brazil \\ ${ }^{3}$ Departamento de Tecnologia de Alimentos, Universidade Federal de Viçosa, Viçosa, MG, Brazil
}

Received 5 September 2018; accepted for publication 4 October 2018

\begin{abstract}
Scientific studies demonstrate the importance of intestinal microbiota to human health and how probiotic microorganisms can positively affect health when administered regularly and in adequate amounts. Probiotic bacteria can be part of fermented products and their functional importance is associated mainly with their metabolism. They are thought to benefit individuals to maintain their health and also to strengthen resistance against various types of diseases. The acceptance of probiotic cultures and products by consumers increased when these bacteria were marketed as natural cultures that help in digestion and health. Considering this, the food industry has an increasing demand for new candidates as probiotic cultures, and the dairy industry has a particular interest for fermented milks and other dairy products, since these are the most common food vehicles for probiotic cultures. Therefore, the dairy industries are increasingly seeking to improve their products with these beneficial bacteria. However, the legal peculiarities and excess of control agencies in Brazil makes the registration of these products and the collection of data very complex. Prospective analysis suggests that probiotic foods have the potential to effect a considerable expansion of the dairy industry, allowing the dairy sector to grow and for these products to be increasingly sought by consumers globally. For this, not only actions on research and innovation are necessary, but also official clarifications on the claims for considerations of microbiological security and functionality of these products. This review aims to elucidate important probiotic research regarding the isolation and characterization of beneficial cultures in Brazil, and to demonstrate the relevance of the dairy chain as a potential source of novel cultures for the development of new probiotic products to expand the Brazilian dairy industry.
\end{abstract}

Keywords: Brazil, dairy, lactic acid bacteria, probiotics.

According to $\mathrm{FAO} / \mathrm{WHO}$, probiotics are defined as living organisms that benefit consumer health when ingested in appropriate concentrations (Sanders, 2008). Most of the probiotics used by the food industry are lactic acid bacteria $(\mathrm{LAB})$, because of their essential role in nutrition and food processing (Kechagia et al. 2013). LAB strains are usually incorporated in fermented food products as starter cultures and their beneficial/functional importance is associated mainly with their metabolism, such as substrate utilization and metabolite production capacities, as well as their direct beneficial properties (Oh \& Jung, 2015). The acceptance of probiotic strains and products by consumers increased when these bacteria were marketed as natural cultures that help in digestion processes and health (Kechagia

*For correspondence; e-mail: nero@ufv.br et al. 2013). The use of food products containing probiotic bacteria covers a large part of the population, however therapeutic applications of $L A B$ have a more limited scope (Foligné et al. 2013).

In Brazil there is a growing market for probiotic food products. Brazilian consumers are becoming more aware about the health benefits of probiotic foods, and the food industry is following this trend, offering different alternatives (Pimentel et al. 2017). Dairy is the main sector associated with probiotic foods in Brazil (Granato et al. 2010) and the regulations for the production and certification are shared by the Ministry of Agriculture and the Ministry of Health; the first is responsible for registering and provide guidelines for production of the dairy products, while the second is responsible for assessing the beneficial properties and to regulate the usage of specific strains as probiotics.

In this review, we present the main aspects related to the characterization of probiotic and beneficial LAB strains with 


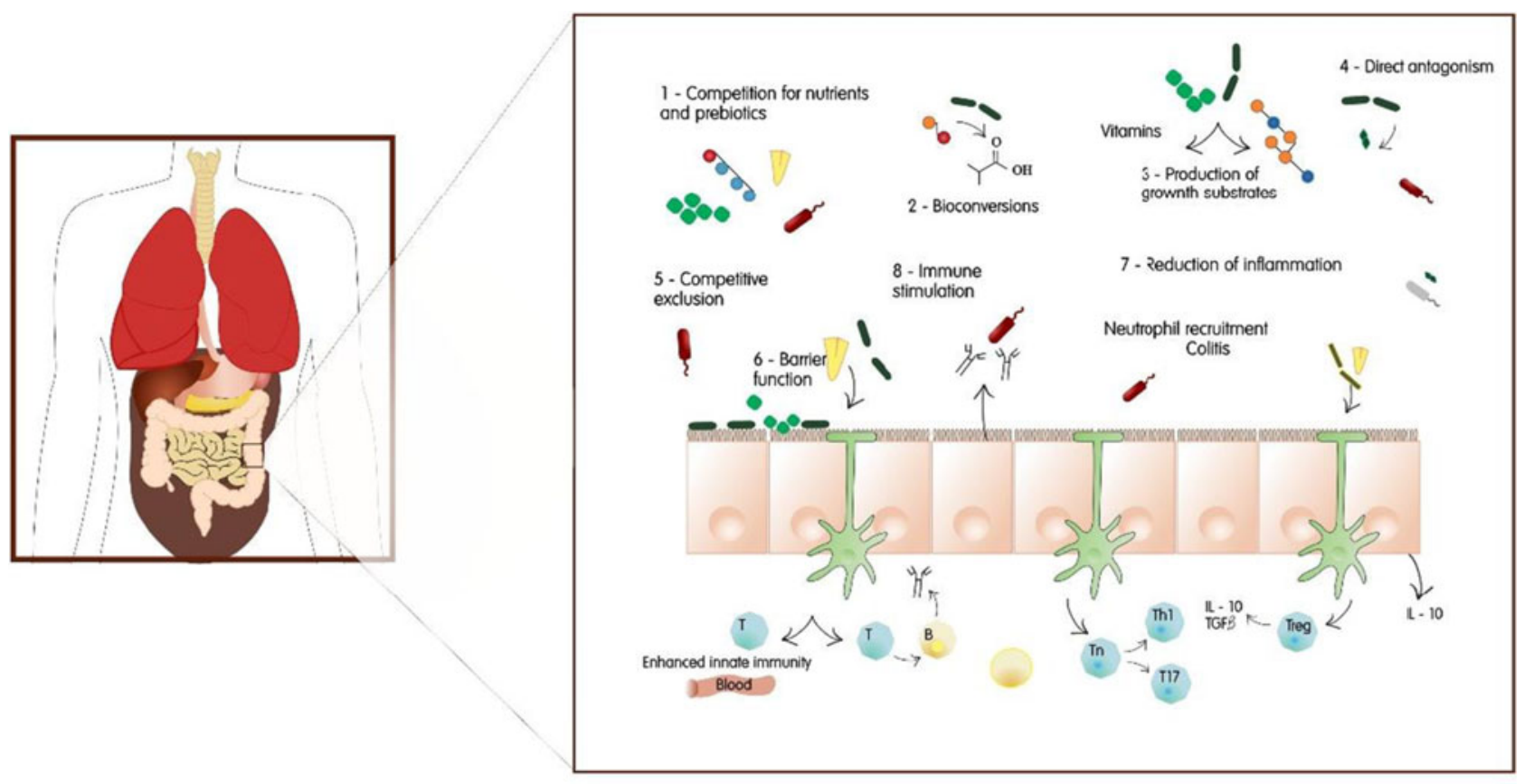

Fig. 1. Probiotic action mechanisms.

potential application in the dairy industry and the Brazilian scenario regarding this topic.

\section{Definitions, benefits and selection criteria}

Over the past 20 years research in the area of probiotics has progressed considerably, with significant advances in the selection and characterization of probiotic cultures, focusing on benefits to consumer health (Kerry et al. 2018). Several studies characterise the beneficial activity of these microorganisms as well as their applications in the production of traditional and commercial fermented foods. Probiotic microorganisms are represented by different species, including bacteria, yeasts and moulds: $L A B$ are the main explored organisms in the food industry, and strains from genera Lactobacillus, Bifidobacterium and Streptococcus are the focus of scientific studies and use in dairy processing (Reid, 2015; Hossain et al. 2017). Among other bacteria, strains of Pediococcus, Propionibacterium, Enterococcus and Lactococcus are also widely explored due to their beneficial aspects (Fontana et al. 2013; Kechagia et al. 2013; Amara \& Shibl, 2015; Kerry et al. 2018).

Beyond the beneficial properties of LAB linked to their probiotic activity, these organisms are commonly used in fermented food products as starter or non-starter cultures and their importance is mainly associated with their metabolism, such as the use of substrates and generation of different products (Konings et al. 2000; Oh \& Jung, 2015). LAB are characterised by their spoilage activity, their organoleptic characteristics, the determination of their products and their interference in the survival of foodborne pathogens (Konings et al. 2000). These bacteria can produce substances with antimicrobial activity against spoilage and pathogenic microorganisms (Zacharof \& Lovitt, 2012).

Probiotic LAB are mainly used in applications related to the gastrointestinal tract, however, their use can be extended to the skin, oral and vaginal health (Foligné et al. 2013). In the last decade reports have shown that even dead cells, or cell parts, of these microorganisms have a positive effect on the human immune system (Kerry et al. 2018). Little is known about how probiotics influence host intestinal microbiota, therefore, the mechanisms for their beneficial effects are difficult to determine due to their multifactorial nature, which includes: gut microbiota modification, competitive adherence to the mucosa and epithelium, gut epithelial barrier strengthening and immune system modulation. All of these convey advantages to the host (Fontana et al. 2013). This occurs by means of protein and short chain fatty acid production, lowering of gut $\mathrm{pH}$ and nutrient competition that stimulates mucosal barrier function and immunomodulation (Ahire et al. 2013). Immunomodulation has been the most studied issue and is verified by the capacity of probiotics to induce phagocytosis and IgA secretion, modifying T-cell responses, enhancing Th1 responses, and attenuating Th2 responses (Kechagia et al. 2013). Although the mechanisms of action of these microorganisms are not yet completely understood, their health benefits and safety for human consumption has growing scientific evidence. Probiotic effects tend to be strain specific: each strain can bring different benefits to the host (Fontana et al. 2013; Amara \& Shibl, 2015). Figure 1 shows the mechanisms of activity of a probiotic bacterium, and Fig. 2 shows the benefits of probiotic bacteria in the host organism. 


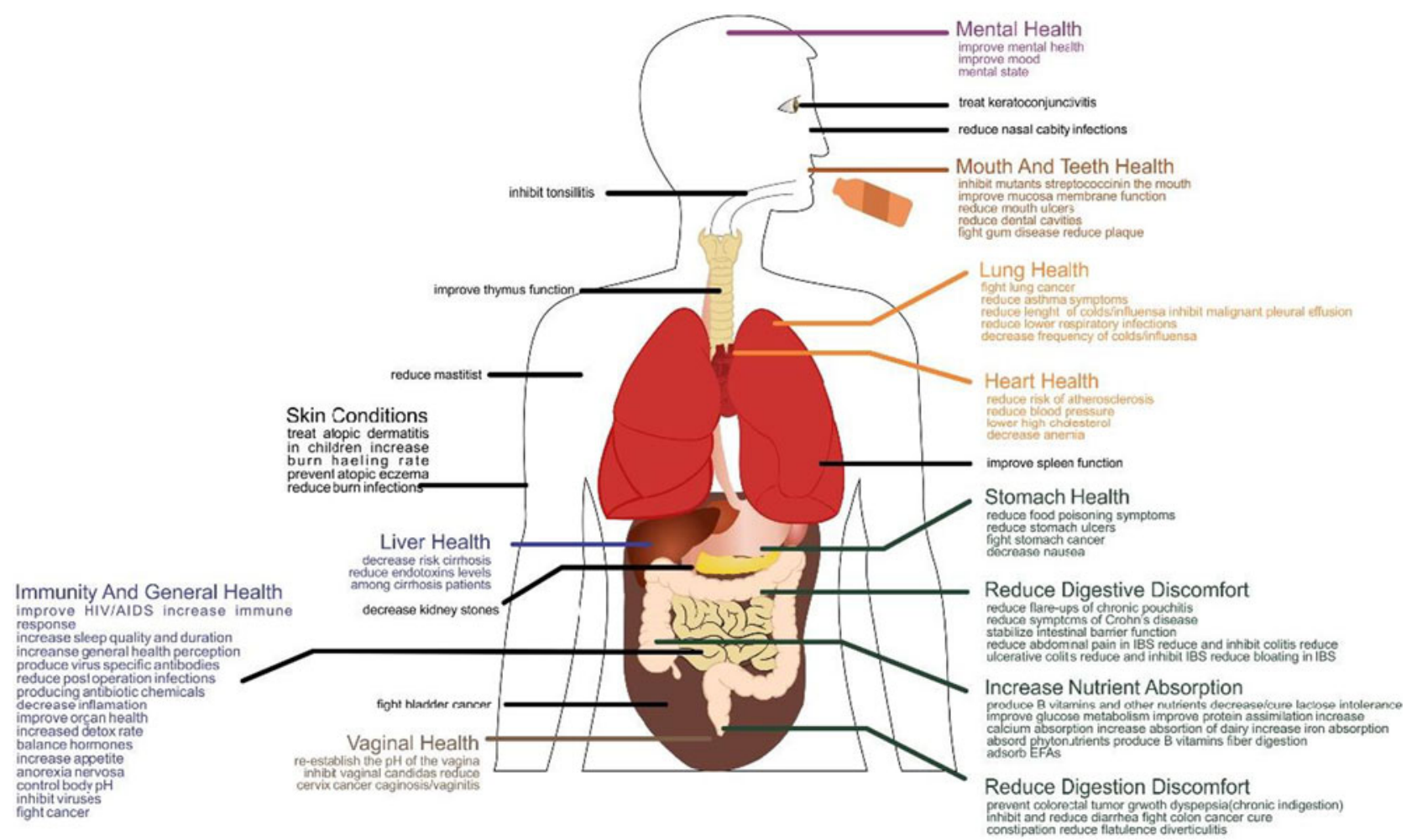

Fig. 2. Beneficial effects of probiotic bacteria.

The first step for obtaining novel probiotic strains is the enumeration and isolation of bacteria from a target group and the characterization of selected isolates by conventional and molecular approaches. Different culture media and protocols can be considered during this first step of screening, and conventional plating is mandatory, since it is necessary to obtain isolated colonies for further testing (Davis, 2014). So, antibiotics, chemicals and incubation conditions are often considered to create selective conditions to improve the growth of target groups, mainly LAB (Colombo et al. 2014; Miranda et al. 2014). The isolates must be fully characterized by phenotypical and molecular methods, in order to identify their species and main characteristics. The criteria for selection of new probiotic species include features related to safety and efficacy, as well as technological aspects of the cultures to be used in the product composition. Finally, the approval also depends on depositing the culture in a registered collection of microorganisms, a systematic revision about the use of this species as probiotics, tests in animals and clinical controlled tests in humans (Hossain et al. 2017).

A potential probiotic organism must come from healthy animals, be commensal inhabitants of the intestine and be non-toxic and non-pathogenic (Salminen et al. 1999). The efficacy or functionality of a strain is related to its ability to withstand the harsh conditions of the gastrointestinal tract (action of bile, gastric, pancreatic and enteric juices), as well as possession of antagonistic activity against resident pathogens (Salminen et al. 1999; Kerry et al. 2018). The selected strains may also present adequate technological properties, such as easy manipulation, fast growth in vitro, stability during storage (surviving in the final product at a predictable concentration and retaining function) and ability to multiply along with autochthonous microbiota of the host (Salminen et al. 1999). Finally, animal models and in vivo tests are fundamental to the culture definition as probiotic (Hossain et al. 2017).

Despite the great interest of the industry in using probiotic cultures in food products to impart benefits to consumers, the use of these strains requires great caution due to the possibility of transferring their resistance or virulent genes to other microorganisms. The possibility of vertical transfer of genes between probiotic cultures and other bacteria is a concern in the food industry (Franz et al. 2011). Probiotic can have resistance to different antibiotics and carry genes related to these characteristics, increasing their potential virulence (Franz et al. 2011; Zhang et al. 2016). Also, strains that possess virulence genes can express them in food, presenting a risk to consumers (Moraes et al. 2012; Zhang et al. 2016). This is particularly a concern for probiotic strains of Enterococcus spp. that harbour several virulence related genes and present a high potential of gene transfer.

\section{Probiotics in the dairy industry}

Probiotic cultures have been isolated from several food systems and animal environments, including dairy (Fontana 
Table 1. Examples of some Brazilian dairy products that carry probiotic bacteria, available in retails sale for consumers

\begin{tabular}{|c|c|c|c|}
\hline Dairy product & Commercial name & Producer & Probiotic strain \\
\hline \multirow[t]{9}{*}{ Fermented milk } & Yakult ${ }^{\circledR}$ & Yakult $^{\circledR}$ & Lactobacillus casei Shirota \\
\hline & Chamyto $^{\circledR}$ & Nestlée ${ }^{\circledR}$ & L. paracasei \\
\hline & Ninho Soleil ${ }^{\circledR}$ & Nestlé ${ }^{\circledR}$ & L. paracasei \\
\hline & Activia $^{\circledR}$ & Danone $^{\circledR}$ & Bifidobacterium animalis CN173010 \\
\hline & Actimel $^{\circledR}$ & Danone $^{\circledR}$ & L. casei defensis \\
\hline & Danito $^{\circledR}$ & Danone $^{\circledR}$ & L. casei \\
\hline & Parmalat $^{\circledR}$ & Parmalat $^{\circledR}$ & L. acidophilius, L. casei, B. animalis \\
\hline & Batavito $^{\circledR}$ & Batavo $^{\circledR}$ & L. casei, L. acidophilus \\
\hline & LC1 Active ${ }^{\circledR}$ & Danone $^{\circledR}$ & L. acidophilus \\
\hline \multirow[t]{5}{*}{ Yogurt } & Activia $^{\circledR}$ & Danone $^{\circledR}$ & B. animalis CN173010 \\
\hline & Lective $^{\circledR}$ & $\operatorname{Vigor}^{\circledR}$ & B. animalis subsp. animalis \\
\hline & Biofibras $^{\circledR}$ & Batavo $^{\circledR}$ & B. lactis, L. acidophilus \\
\hline & Nesvita ${ }^{\circledR}$ & Nestlé ${ }^{\circledR}$ & B. lactis \\
\hline & Plenus $^{\circledR}$ & Itambé ${ }^{\circledR}$ & B. lactis, L. acidophilus \\
\hline \multirow[t]{2}{*}{ Cheese (fresh) } & Sanbios ${ }^{\circledR}$ & Santa Clara ${ }^{\circledR}$ & B. animalis subsp. lactis $\mathrm{Bi}-07$ \\
\hline & Stímula ${ }^{\circledR}$ & Balkis $^{\circledR}$ & L. acidophilus \\
\hline \multirow[t]{2}{*}{ Dairy dessert } & Sofyl ${ }^{\circledR}$ & Yakult $^{\circledR}$ & L. casei Shirota \\
\hline & Activia $^{\circledR}$ & Danone $^{\circledR}$ & B. animalis CN173010 \\
\hline Infant formula & Nan Probio $2^{\circledR}$ & Nestlé & B. longum, L. rhamnosus \\
\hline
\end{tabular}

Source: Pimentel et al. (2017) and Granato et al. (2010).

et al. 2013). Dairy industries are often seeking for novel probiotic and beneficial strains, in order to develop novel dairy products to be offered to consumers as alternatives to keep their health and well-being (Reid, 2015). Since the 1990s, fermented milk products have received significant attention because of the presence of these probiotic microorganisms in their composition; dairy products are the main vehicle for administration of probiotics at optimal concentrations for consumers $\left(10^{8}-10^{9}\right.$ UFC per day, depending on the recommended diary ingestion for each product). Moreover, there is a long history of safe use of fermented dairy products, which would facilitate the security verification of these products (Fontana et al. 2013). Fermented milks are usually considered as ideal vehicles for probiotic strains, but other dairy products, such as fresh cheeses, are being increasingly used with this purpose.

\section{Brazilian scenario for probiotics in the dairy industry: legal framework}

The growing demand for dairy products in Brazil has led to an expansion of both the dairy industry and the producers responsible for providing quality raw material. In this context, the development of novel products, including probiotics, is a current trend: as the quality of raw milk produced in Brazil is improving, new fermented products are being developed. As consequence, Brazilian dairy industry offers to the consumers a panel of alternative probiotic dairy products, as described by Pimentel et al. (2017) and Granato et al. (2010), composed mainly of fermented milks (Table 1).

However, this number is restricted by the historical difficulties related to Brazilian legislation.
Two Governmental institutions shared the regulations towards probiotics in Brazil. The Ministry of Health assess the beneficial and probiotic potential of the strains that will be used in the dairy production through the National Health Surveillance Agency (ANVISA), responsible for the registration of products and authorization of health-related companies, such as medicines, food and cosmetics. The Ministry of Agriculture (MAPA) is responsible for inspecting the dairy industries and registering the dairy products that will be produced under these inspection rules. Considering the different competences of MAPA and ANVISA regarding dairy products with claims of functionality, there is an agreement between these agencies. Thus, when a company has an interest in using functional and/or health claims in products that are of MAPA's competence, the company must first apply an evaluation form to request the allegation to ANVISA, which proclaims the decision to the company with a copy to the competent MAPA area. Likewise, when a new ingredient, including probiotic, is used in products of MAPA's competence, the company must request the evaluation of safety of use to ANVISA before the product is approved. After registration, MAPA is responsible for monitoring if the product maintains the quantities of probiotics described and sufficient for the claim.

ANVISA has published at least 12 regulatory rules in the last 20 years related to registration of new products and claims of functionality, including probiotics. They subdivide the products containing probiotics into 5 categories: medicines (Brazil, 2003), food (Brazil, 1999a, b, c, d), infant and enteral foods (Brazil, 2011a, b, c), supplements (Brazil 1999b, d) and supplements with added vitamins and minerals (Brazil, 2002). More recently, it has published the RDC no. $241 / 2018$, which provides the requirements 
for proving the safety and health benefits of probiotics for use in food. It was published after a public consultation with the aim of defining more specific criteria for the evaluation of the safety and benefits of probiotics (Brazil, 2018). Together, these resolutions deal with the product registration process, applications for claims of functionality and probiotic properties, labelling and marketing about these characteristics. Added to this web of resolutions is the lack of an official unified list containing pre-approved species or strains of probiotic microorganisms and the impossibility of registering patents of living organisms in Brazil. Although the Agency's website contains a list of ten species of probiotic microorganisms, the ANVISA reports forecast the publication of an official list with strains approved as probiotics still for 2018. The General Food Management of ANVISA (GGALI) started the construction of the list and only three strains were considered suitable to be included in the Normative Instruction, namely: Bacillus coagulans GBI-30, Bifidobacterium lactis HN019 and Lactobacillus reuteri DSM 17938.

The complexity of the Brazilian regulatory system results in a low number of applications for registration of food with probiotics in Brazil and, mainly, a high number of rejections for probiotic claims relating to these products. Numbers provided by the Agency indicate that between 1999 and 2017, from the 211 applications for the registration of food containing probiotics, only 66 were deferred, while 100 were denied. The others are still under analysis. Only 12 products are registered in the Agency's General Food Management within the category of bioactive and probiotic substances isolated with claims of functionality and/or health properties. The main reasons for rejecting an application, according to the Agency, are the use of inappropriate methods for identification of the microorganism, lack of conclusive experiments on the safe use of this strain for humans and inconsistences between the claimed effects and the efficacy studies contained in the dossier.

The new legislation about probiotics in foods in Brazil foresees that the acceptance of the claimed benefit will occur after a positive conclusion regarding three areas: identification, proof of safety and proof of health benefits of the strain (Brazil, 2018). The identification must be carried out at the lineage level by means of phenotypic and genotypic tests and the deposit of the lineage into a collection of cultures recognized internationally. The proof of safety depends on the group to which the product will be administered and if the species already has security status considered in other international health agencies. Technical papers and scientific articles are considered for this issue. In general, in addition to the history of safe use, the absence of virulence and pathogenicity factors and non-production of metabolites that pose a risk to human health, as well as the safety of use in terms of antibiotic resistance, should also be considered. Finally, the health benefits should be communicated through evidence of functional or health property approved for the strain, which may be general or specific, although the criteria for each type of claim are not detailed in the RDC, but rather in complementary guides published by the Agency. General claims will require only a clinical study with evidence of the benefits of ingestion of the micro-organism. Specific claims will be for new claims, irrespective of micro-organisms, and will call for further studies to complete the claim. In addition to demonstrating the ability of the strain to survive the human digestive tract conditions, evidence of the beneficial effects on humans should involve a representative group of the population of interest, considering the claim, and considering the minimum amount suggested to obtain the benefit. Once the lineage has been approved for the claimed benefit, new products containing this lineage need not be subject to further approval.

Some publications from this Agency try to help companies to register new probiotics, as guides to fulfil requests and containing the steps needed for registration (available at http://portal.anvisa.gov.br/documents/3845226/0/Guia +Probioticos_Portal.pdf/e1bbf33e-719e-4f3e-84a0-7846 bbe17972). However, the decision-making process is still subjective and has constantly changed since 2002, and more intensively since 2010 . Some of these changes are positive, as they have made the evaluation of applications more specific and based on international guides and scientific knowledge. Regulatory predictability, with clear information to companies, and an agile decision-making process are essential requirements to ensure that the innovations demanded by consumers and generated by the industry come true.

\section{Brazilian scenario for probiotics in the dairy industry: scientific studies on probiotic dairy products}

Probiotic culture isolation and characterization is a prominent area of research in Brazil. Many Brazilian researchers have found in foods and dairy products, as well as environments and different regions, a potential source of new probiotic cultures that might be used in new products. Kefir grains are the focus of some of these studies. Lima et al. (2017) assessed the probiotic properties of Saccharomyces cerevisiae isolated from kefir, demonstrating that some strains presented antagonistic activity against important pathogens, such as Klebsiella pneumoniae, Pseudomonas aeruginosa, Staphylococcus aureus, Bacillus subtilis, as well as important beneficial features. Vieira et al. (2017) tracked potential probiotic $\mathrm{LAB}$ strains isolated from Brazilian kefir grains with the ability to produce conjugated linoleic acid (CLA) during the fermentation of whole cow milk, a compound reputed to be of significant importance to health at low ingestion rates, leading to reductions in cancer incidence and severity of atherosclerosis. Although the bacterial production of CLA in foods is considered a technological challenge, the results were encouraging. Working with kefir, Zanirati et al. (2015) evaluated diverse cultures with probiotic potential, such as species of the genera Lactococcus, Leuconostoc, Lactobacillus and Oenococcus, and also demonstrated the possibility of using yeasts in combination 
with bacterial cultures. Leite et al. (2013) reviewed several studies of isolation and characterization of microbiological, technological and therapeutic properties of kefir conferred on the symbiotic associations between bacteria and yeasts, and they highlighted the beneficial effects that could be provided by these co-cultures such as antimicrobial, antitumor, anticarcinogenic, hypo-allergenic and immunomodulating properties. In addition, they emphasized the importance of this dairy beverage in the daily food choices of diverse populations as well as the microbial diversity related to its origin.

Several studies show the importance of cheeses produced in Brazil as a fundamental source of probiotic microbiota. Martins et al. (2018) studied the bacterial diversity found in artisanal cheeses of the Amazon region (Pará) comparing between the dry and rainy seasons. Several genera were identified, predominant amongst them being Lactobacillus, Lactococcus, Enterococcus, Weissella, Pediococcus and Leuconostoc. In addition, this study showed the importance of current molecular approaches combined with culturedependent methods in the detailed analysis of the microbial ecology of traditional cheeses from the Amazon region of northern Brazil. Campagnollo et al. (2018) selected native LAB from Brazilian artisanal cheeses produced with raw milk and characterized them as antagonist against pathogens. They also produced soft and semi-hard Minas cheeses, added the selected LABs and were able to identify strains of $L$. brevis and $L$. plantarum as potential beneficial cultures with anti-listerial activity. Studies like these show the importance of these beneficial cultures as an additional barrier to the growth of Listeria monocytogenes during storage of refrigerated soft cheeses, and at the same time the cultures shorten the semi-hard cheese ripening period when aged at room temperature. Acurcio et al. (2017) and Sant'Anna et al. (2017) isolated strains of L. plantarum and Pediococcus acidilactici from Brazilian artisanal cheeses and inoculated them in fermented milk. Feeding of the fermented milk to mice challenged with Salmonella typhimurium in controlled in vivo experiments demonstrated a protective effect, with less translocation and reduction of the pathogenic population and a consequent reduction of histological lesions, weight loss and mortality. Perin et al. (2017) studied the bacterial ecology of artisanal Minas cheese and identified four genera: Lactobacillus, Lactococcus, Enterococcus and Weissella, with Lactobacillus being the most prevalent genus. In addition, the authors concluded that the microbiota of the Minas artisanal cheese is strongly influenced by its geographic origin as well as by the farm in isolation, which can be explained by the lack of standardization in the production procedures. In the study of Castro et al. (2016), besides the artisanal Minas cheeses, lactic microbiota of water and raw milk were also identified and characterized. In this study, E. faecalis, L. lactis and L. plantarum strains were isolated from the cheese; L. brevis, E. pseudoavium, E. durans and Aerococcus viridans were isolated from endogenous starter cultures and described for the first time in the literature. The LAB identified in the sampled cheeses may inhibit the undesirable microbiota and contribute to the safety and flavour of the cheese. Paula et al. (2015) isolated a Leuconostoc mesenteroides strain from buffalo mozzarella cheese and characterized its probiotic potential, identifying higher functional properties compared to other strains studied. Thus, the authors were able to state that the $L$. mesenteroides strain is a potential candidate for application in functional milk-based foods. Coalho is another very popular artisanal Brazilian cheese, from which Santos et al. (2015) isolated strains of L. rhamnosus and L. plantarum with beneficial potential. The same authors carried out a study characterizing the beneficial potential of E. faecium strains of Brazilian artisanal cheeses, characterizing them as bacteriocinogenic and thus excellent candidates to be used in probiotic products (Santos et al. 2014). Tulini et al. (2013) also identified and characterized the bacteriocinogenic potential of a $L$. paraplantarum strain isolated from semi-hard Minas cheese. Overall, the results of this study indicated that L. paraplantarum is a potential probiotic and its production of bacteriocin may be an interesting feature for food applications. Finally, it is worth mentioning the importance of the production of goats and sheep in Brazil, as well as the production of dairy products derived from these species. Meira et al. (2012) isolated Lactobacillus strains from Brazilian regional sheep cheese, obtaining strains with interesting functional characteristics, mainly of the species L. brevis and L. plantarum as potential probiotic strains.

In addition to dairy products as main sources of probiotic cultures, milk itself (of various species) as well as the production environment can also be important. Moraes et al. (2017) isolated and characterized LAB isolates from goat milk: L. mucosae strains attracted the attention of recent research due to their ability to adhere to the intestinal mucosa and inhibit pathogens in the gastrointestinal tract, both related to probiotic potential. Collectively, the results point to $L$. mucosae as a promising candidate for probiotic dairy products. Freitas et al. (2015) studied the biodiversity of milk propionibacteria isolated from dairy farms in Minas Gerais, Brazil; bacteria belonging to this genus are known to be widely used in the maturation phase of Swiss-type cheeses, and in this study, the authors observed the considerable genetic diversity of wild propionibacteria in milk collected from different farms, with different origin (raw milk, silage, soil and pasture). In addition, different genetic profiles were found, indicating specific niches for each locality. These results show the dairy farms environment and milk production as excellent reservoirs for Propionibacterium strains and its future use as starter or probiotic cultures, as well as in the study of the prevention of cheese defects. Although not well reported, there are also studies showing the phenotypic and genotypic heterogeneity of probiotic species isolated from various foods (raw and pasteurized milk, meat products, cheeses and vegetables). Riboldi et al. (2008) and Gomes et al. (2008) were able to investigate and determine the phenotypic and genetic diversity in enterococci isolated from different 
dietary sources. Genetic diversity was highest in E. faecium and $E$. faecalis isolates obtained from dairy products. Isolated samples of meat and vegetables offered the greatest genotypic variability.

\section{Brazilian scenario for probiotics in the dairy industry: development of dairy products with probiotic cultures}

The development of new food products becomes increasingly challenging as it seeks to meet consumer demand for products that are healthy and attractive. In Brazil, many studies propose the development of novel products based on Brazilian consumer taste, and exploring the beneficial strains isolated in Brazilian products, mainly from dairy origin. Fermented dairy beverages are the best known and easily produced: there are several studies demonstrating the proven benefits and quality of fermented milks added to probiotic cultures.

Weschenfelder et al. (2018) developed a kefir and evaluated its composition and antagonistic activity against $S$. aureus and $E$. coli. The authors investigated whether the kefir produced was able to meet the identity and quality standards of fermented milks, verifying the possibility of assigning a nutritional declaration. As a result, the authors were able to identify significant antagonistic activity against the tested microorganisms and suggest that further studies are carried out in order to explore their potential as a probiotic food and its inclusion in the diet of the population. Oliveira et al. (2016) produced a frozen yogurt of goat milk with the flavour of cajá (Spondias mombim L.), a typical Brazilian fruit of the Cerrado and managed to identify the product as appealing to the food industry. Batista et al. (2015) produced a probiotic yogurt with added glucose oxidase and evaluated its microbiological, physical-chemical and metabolic parameters. The product showed adequate viability of the dairy and probiotic cultures. With this study, the authors were able to conclude from a functional food perspective that the addition of glucose oxidase to probiotic yogurts may be an interesting technological option for small and medium dairy companies to enter the functional dairy market. Pimentel et al. (2012) produced a probiotic yogurt with traditional $L A B$ and a strain of $L$. paracasei ssp. paracasei as probiotic. In addition, inulintype fructose of varying degrees of polymerization were added, and the results showed that such addition does not negatively affect the physical-chemical and microbiological characteristics of yogurts and their storage stability. In this way, it can be concluded that the selection of the type to be used depends on the manufacturer objective and the intended use. Mazochi et al. (2010) produced a probiotic yogurt with goat milk supplemented with Bifidobacterium spp., supplemented or not with strawberry flavour. The data enabled the product to be accepted by the Brazilian legislation. In the studies of Viegas et al. (2010) and Oliveira et al. (2002), functional fermented milks were also produced from $\mathrm{LAB}$ cultures isolated from Coalho cheese and other lactic sources, respectively. Both studies confirm the recommendation of using probiotic cultures in association and are recommended for industrial elaboration of new probiotic fermented milks using Brazilian lactic cultures as starter or probiotics.

In addition to fermented milks, some studies demonstrate the potential of cheeses as potential carriers of probiotic cultures. Ferreira et al. (2017) aimed to develop a probiotic culture isolated from Amazonian cheese (Marajó cheese) made from raw buffalo milk for industrial applications using lyophilization and spray drying. Although the survival rate was similar among the samples evaluated after drying, the technological performance of the skimmed milk showed some differences. This study will help to direct further investigations on how to preserve probiotic LAB to produce spray dried primers that have a high number of viable cells and can then be used for industrial applications economically. Oliveira et al. (2012, 2014) and Garcia et al. (2012) added probiotic bacteria to Brazilian semi-hard goat cheese (Coalho) and concluded that goat cheese may be an interesting vehicle for probiotic $L$. acidophilus, L. casei subsp. paracasei and B. lactis. In addition, L. casei subsp. paracasei can be used as protective culture to slow the growth of $S$. aureus and L. monocytogenes in goat cheese. In similar fashion, Ribeiro et al. (2009) have developed a Brazilian Minas cheese with $L$. acidophilus produced with retentate obtained by ultrafiltration of milk.

In addition to the conventional dairy products, such as cheeses and fermented milk, some studies propose the development of novel and innovative products for the area. Addition of honey produced by stingless bees to goat yogurt containing a $L$. acidophilus probiotic strain resulted in a successful incorporation, with satisfactory nutritional quality (Machado et al. 2017). Figueiredo et al. (2015) have developed a powdered milk supplemented with $L$. acidophilus and, although during drying of milk most cells die, the authors were able to conclude that production of this novel probiotic food is feasible. Silva et al. (2012) produced a chocolate pudding with added $L$. casei, characterizing this dessert as an excellent carrier of probiotic microorganisms. Antunes et al. (2007a, b) have developed butter and buttermilk probiotics, respectively: both new products presented the desired requirements regarding safety and the number of probiotic bacteria.

\section{Brazilian scenario for probiotics in the dairy industry: Acceptance of probiotic dairy products by consumers}

It is understood that a product suitable to meet the needs and desires of the consumer has a greater chance of winning a certain audience and often the product is given value by the consumer who feels that the expectations are reached. As a result, more and more studies and research are needed with consumers, so that they are able to classify various foods as to their acceptability, and this certainly 
also applies to probiotic foods. Different Brazilian studies have demonstrated the acceptance of the Brazilian consumers for such probiotic dairy products.

Esmerino et al. (2017) identified the main aspects involved in the perception of consumers regarding yogurts, fermented milk beverages and fermented. Although minor differences were observed, similar conclusions could generally be obtained from the study. The importance of such discoveries lies in helping dairy companies provide subsidies and guidelines for product redesign, marketing strategies, and improved communication between producers and consumers of different fermented dairy products. In the study of Machado et al. (2017), the authors achieved a successful incorporation involving honey and probiotic culture (L. acidophilus) into a new goat dairy product with satisfactory nutritional and sensory quality and added value to the market. Oliveira et al. (2016) demonstrated the good acceptance and improvement of the sensory characteristics of a frozen goat milk yogurt flavoured with cajá. Costa et al. (2014) studied the taste perception of probiotic and conventional yogurts made from goat milk. Although this product is an excellent source of fatty acids, proteins and minerals, it is not well accepted by many consumers due to its typical flavour derived from the caprylic, capric and caproic acids present in this milk and dairy products: in this study, the authors were able to conclude that with regard to rapid repeated exposure, only six days were enough to significantly increase consumer familiarity with goat milk yogurt and probiotic goat milk yogurt. Thus, the authors could infer that increasing exposure sessions could be a strategy to increase acceptance of goat milk. Yogurt containing glucose oxidase from the study of Cruz et al. (2013) through sensorial methodologies using consumer responses presented potential options for the characterization of food matrices with diverse sensorial sensations.

Barros et al. (2016) studied the attitude and opinion of consumers regarding different types of fresh cheeses. Products with different characteristics were used to encourage discussion among participants, including cheese with 'no added salt', the claim 'contains probiotic microorganisms' and products processed with goat milk. As results, the authors assumed that consumers would buy cheese with reduced salt if it did not have its flavour compromised; also, although the claim to contain probiotic in the product is not known to consumers, many have stated that they would buy the product. Garcia et al. (2012) developed a Brazilian semi-hard goat cheese with addition of probiotic $\mathrm{LAB}$ and obtained the best sensory scores in the acceptance test, purchase intention and preference sorting test. In the study of Ribeiro et al. (2009), the authors were able to develop a Minas pasta cheese with $L$. acidophilus produced with retentate obtained by milk ultrafiltration and had as a result of sensorial analysis a positive result by the acceptance of consumers. Studies such as these are likely to reveal important implications for marketing development strategies for probiotic foods.

\section{Concluding remarks}

There is little doubt between scientists about the benefits to human health of incorporating probiotics into food products. Specific probiotic treatments are also important for the prevention and control of diseases. Moreover, the increasing consumer awareness about the benefits of these microorganisms has meant that probiotic products have become increasingly popular and represent an important functional food market. In Brazil, despite the limitations and complexity of the regulations about probiotics, artisanal products and the dairy production chain are considered as relevant sources of beneficial strains, and have stimulated scientific studies to characterize them and also to develop novel dairy products, with good acceptance by the consumers.

The authors would like to thank CAPES, CNPq, FAPEMIG.

\section{References}

Acurcio LB, Sandes SHC, Bastos RW, Sant'Anna FM, Pedroso S, Reis DC, Nunes AC, Cassali GD, Souza MR \& Nicoli JR 2017 Milk fermented by Lactobacillus species from Brazilian artisanal cheese protect germ-freemice against Salmonella typhimurium infection. Beneficial Microbes 8 579-588

Ahire JJ, Mokashe NU, Patil HJ \& Chaudhari BL 2013 Antioxidative potential of folate producing probiotic Lactobacillus helveticus CD6. Journal of Food Science and Technology 50 26-34

Amara AA \& Shibl A 2015 Role of probiotics in health improvement, infection control and disease treatment and management. Saudi Pharmaceutical Journal 23 107-114

Antunes AEC, Grael ET, Moreno I, Rodrigues LG, Dourado FM, Saccaro DM \& Lerayer ALS 2007a Selective enumeration and viability of Bifidobacterium animalis subsp. lactis in a new fermented milk product. Brazilian Journal of Microbiology 38 173-177

Antunes AEC, Marasca ETG, Moreno I, Dourado FM, Rodrigues LG \& Lerayer AL 2007b Development of a probiotic buttermilk. Ciencia e Tecnologia de Alimentos 27 83-90

Barros CP, Rosenthal A, Walter EHM \& Deliza R 2016 Consumers' attitude and opinion towards different types of fresh cheese: an exploratory study. Food Science and Technology 36 448-455

Batista ALD, Silva R, Cappato LP, Almada CN, Garcia RKA, Silva MC, Raices RSL, Arellano DB, Sant'Ana AS, Conte CA, Freitas MQ \& Cruz AG 2015 Quality parameters of probiotic yogurt added to glucose oxidase compared to commercial products through microbiological, physical-chemical and metabolic activity analyses. Food Research International 77 627-635

Brazil 1999a Resolução n 16, 1999 April 30 - Technical guidelines for registering foods and novel ingredients. In Book Resolução n 16, 1999 April 30 - , Vol. Resolução 16, pp. (Ed.^Eds. Editor).Series Resolução n 16 , 1999 April 30 -.

Brazil 1999b Resolução n 19, 1999 April 30 - Approves the technical guidelines for registering foods with functional and health benefits properties in their label. In Book Resolução n 19, 1999 April 30 -, Vol. Resolução 19, pp. (Ed.^Eds. Editor).Series Resolução $n^{\circ} 19$, 1999 April 30 -.

Brazil 1999c Resolução RDC n 17, 1999 November 19 - update of Resolução n 362, from 1999 July 29. In Book Resolução RDC n 17, 1999 November 19 - , Vol. Resolução RDC 17, pp. (Ed.^Eds. Editor). Series Resolução RDC n 17, 1999 November $19-$.

Brazil 1999d Resolução RDC n 18, 1999 November 19 - Update of Resolução n 363, from 1999 July 29. In Book Resolução RDC n 18, 1999 November 19 - , Vol. Resolução RDC 18, pp. (Ed.^Eds. Editor). Series Resolução RDC n 18, 1999 November 19 -. 
Brazil 2002 Resolução RDC n², 2002 January 07 - Technical guidelines for bioactive substances and probiotic isolates with health or beneficial properties. In Book Resolução RDC n 2, 2002 January 07 - , Vol. Resolução RDC $\mathrm{n}^{\circ} 2$, pp. (Ed.^Eds. Editor).Series Resolução RDC n 2, 2002 January 07 -.

Brazil 2003 RDC No 323, 2003 November 10 - Technical guidelines for registering, modification and validation of probiotic medicine register. In Book RDC N 323, 2003 November 10 - , Vol. RDC 323, pp. (Ed.^Eds. Editor).Series RDC No 323, 2003 November 10 - . Ministry of Health

Brazil 2011a Resolução da Diretoria Colegiada - RDC n 43, 2011 September 19 - Technical guidelines for infant formula for lactants. In Book Resolução da Diretoria Colegiada - RDC n 43, 2011 September 19 - , Vol. RDC 43, pp. (Ed.^Eds. Editor).Series Resolução da Diretoria Colegiada - RDC n 43, 2011 September 19 -.

Brazil 2011b Resolução da Diretoria Colegiada - RDC n 44, 2011 September 19 - Technical guidelines for infant formula for children. In Book Resolução da Diretoria Colegiada - RDC n 44, 2011 September 19 - , Vol. RDC 43, pp. (Ed.^Eds. Editor).Series Resolução da Diretoria Colegiada-RDC n 44, 2011 September 19 -.

Brazil 2011c Resolução da Diretoria Colegiada - RDC n 45, 2011 September 19 - Technical guidelines for infant formula for children with specific diets. In Book Resolução da Diretoria Colegiada - RDC $\mathrm{n}^{\circ}$ 45, 2011 September 19 - , Vol. RDC 45, pp. (Ed.^Eds. Editor).Series Resolução da Diretoria Colegiada - RDC n 45, 2011 September 19 -.

Brazil 2018 RDC n 241, 2018 July 26 - Requests for assessing the safety and health benefits of probiotic bacteria for use in food. In Book RDC $n^{\circ} 241$, 2018 July 26 - , Vol. RDC 241, pp. (Ed.^Eds. Editor).Series RDC n 241 , 2018 July $26-$.

Campagnollo FB, Margalho LP, Kamimura BA, Feliciano MD, Freire L, Lopes LS, Alvarenga VO, Cadavez VAP, Gonzales-Barron U, Schaffner DW \& Sant'Ana AS 2018 Selection of indigenous lactic acid bacteria presenting anti-listerial activity, and their role in reducing the maturation period and assuring the safety of traditional Brazilian cheeses. Food Microbiology 73 288-297

Castro RD, Oliveira LG, Sant'Anna FM, Luiz LMP, Sandes SHC, Silva CIF, Silva AM, Nunes AC, Penna C \& Souza MR 2016 Lactic acid microbiota identification in water, raw milk, endogenous starter culture, and fresh Minas artisanal cheese from the Campo das Vertentes region of Brazil during the dry and rainy seasons. Journal of Dairy Science 99 6086-6096

Colombo M, Oliveira AEZd, Carvalho AFd \& Nero LA 2014 Development of an alternative culture medium for the selective enumeration of Lactobacillus casei in fermented milk. Food Microbiology 39 89-95

Costa MP, Balthazar CF, Franco RM, Marsico ET, Cruz AG \& Conte CA 2014 Changes in expected taste perception of probiotic and conventional yogurts made from goat milk after rapidly repeated exposure. Journal of Dairy Science $\mathbf{9 7}$ 2610-2618

Cruz AG, Cadena RS, Castro WF, Esmerino EA, Rodrigues JB, Gaze L, Faria JAF, Freitas MQ, Deliza R \& Bolini HMA 2013 Consumer perception of probiotic yogurt: performance of check all that apply (CATA), projective mapping, sorting and intensity scale. Food Research International 54 601-610

Davis C 2014 Enumeration of probiotic strains: review of culture-dependent and alternative techniques to quantify viable bacteria. Journal of Microbiological Methods 103 9-17

Esmerino EA, Ferraz JP, Tavares ER, Pinto LPF, Freitas MQ, Cruz AG \& Bolini HMA 2017 Consumers' perceptions toward 3 different fermented dairy products: insights from focus groups, word association, and projective mapping. Journal of Dairy Science 100 8849-8860

Ferreira AA, Huang S, Perrone IT, Schuck P, Jan G \& Carvalho AF 2017 Tracking Amazonian cheese microbial diversity: development of an original, sustainable, and robust starter by freeze drying/spray drying. Journal of Dairy Science 100 6997-7006

Figueiredo HM, Passos FJV, Passos FML, Lourenco LDH, Araujo EAF, Silva LHM \& Guimarães PCD 2015 Powdered milk containing Lactobacillus acidophilus isolated in Brazil. Journal of Food Science and Technology-Mysore $\mathbf{5 2}$ 562-567

Foligné B, Daniel C \& Pot B 2013 Probiotics from research to market: the possibilities, risks and challenges. Current Opinion in Microbiology 16 284-292
Fontana L, Bermudez-Brito M, Plaza-Diaz J, Munoz-Quezada S \& Gil A 2013 Sources, isolation, characterisation and evaluation of probiotics. The British Journal of Nutrition 109(Suppl. 2) S35-S50

Franz CMAP, Huch M, Abriouel H, Holzapfel W \& Gálvez A 2011 Enterococci as probiotics and their implications in food safety. International Journal of Food Microbiology 151(2) 125-140

Freitas R, Chuat V, Madec MN, Nero LA, Thierry A, Valence F \& Carvalho AF 2015 Biodiversity of dairy Propionibacterium isolated from dairy farms in Minas Gerais, Brazil. International Journal of Food Microbiology 203 70-77

Garcia EF, de Oliveira MEG, Queiroga R, Machado TAD \& de Souza EL 2012 Development and quality of a Brazilian semi-hard goat cheese (coalho) with added probiotic lactic acid bacteria. International Journal of Food Sciences and Nutrition 63 947-956

Gomes BC, Esteves CT, Palazzo LCV, Darini ALC, Felis GE, Sechi LA, Franco B \& De Martinis ECP 2008 Prevalence and characterization of Enterococcus spp. isolated from Brazilian foods. Food Microbiology $\mathbf{2 5}$ 668-675

Granato D, Branco GF, Cruz AG, Faria JAF \& Shah NP 2010 Probiotic dairy products as functional foods. Comprehensive Reviews in Food Science and Food Safety 9 455-470

Hossain MI, Sadekuzzaman M \& Ha S-D 2017 Probiotics as potential alternative biocontrol agents in the agriculture and food industries: a review. Food Research International 100 63-73

Kechagia M, Basoulis D, Konstantopoulou S, Dimitriadi D, Gyftopoulou K, Skarmoutsou N \& Fakiri EM 2013 Health benefits of probiotics: a review. ISRN Nutrition 2013481651

Kerry RG, Patra JK, Gouda S, Park Y, Shin H-S \& Das G 2018 Benefaction of probiotics for human health: a review. Journal of Food and Drug Analysis 26 927-939

Konings WN, Kok J, Kuipers OP \& Poolman B 2000 Lactic acid bacteria: the bugs of the new millennium. Current Opinion in Microbiology 3 276-282

Leite AMD, Miguel MAL, Peixoto RS, Rosado AS, Silva JT \& Paschoalin VMF 2013 Microbiological, technological and therapeutic properties of kefir: a natural probiotic beverage. Brazilian Journal of Microbiology 44 341-349

Lima MDF, Souza KMS, Albuquerque WWC, Teixeira JAC, Cavalcanti MTH \& Porto ALF 2017 Saccharomyces cerevisiae from Brazilian kefir-fermented milk: an in vitro evaluation of probiotic properties. Microbial Pathogenesis 110 670-677

Machado T, Oliveira MEG, Campos MIF, Assis POA, Souza EL, Madruga MS, Pacheco MTB, Pintado MME \& Queiroga R 2017 Impact of honey on quality characteristics of goat yogurt containing probiotic Lactobacillus acidophilus. LWT - Food Science and Technology $80221-229$

Martins MCF, Freitas R, Deuvaux JC, Eller MR, Nero LA \& Carvalho AF 2018 Bacterial diversity of artisanal cheese from the Amazonian region of Brazil during the dry and rainy seasons. Food Research International 108 295-300

Mazochi V, Matos FE, Val CH, Diniz DN, Resende AF, Nicoli JR \& Silva AM 2010 Probiotic yogurt produced with goat milk supplemented with Bifidobacterium spp. Arquivo Brasileiro de Medicina Veterinaria e Zootecnia 62 1484-1490

Meira SMM, Helfer VE, Velho RV, Lopes FC \& Brandelli A 2012 Probiotic potential of Lactobacillus spp. isolated from Brazilian regional ovine cheese. Journal of Dairy Research 79 119-127

Miranda RO, Carvalho AF \& Nero LA 2014 Development of a selective culture medium for bifidobacteria, Raffinose-Propionate Lithium Mupirocin (RP-MUP) and assessment of its usage with Petrifilm ${ }^{\mathrm{TM}}$ Aerobic Count plates. Food Microbiology 39 96-102

Moraes P, Perin L, Todorov SD, Silva A, Franco B \& Nero LA 2012 Bacteriocinogenic and virulence potential of Enterococcus isolates obtained from raw milk and cheese. Journal of Applied Microbiology 113 318-328

Moraes GMD, Abreu LR, Egito AS, Salles HO, Silva LMF, Nero LA, Todorov SD \& Santos KMO 2017 Functional properties of Lactobacillus mucosae strains isolated from Brazilian goat milk. Probiotics and Antimicrobial Proteins 9 235-245

Oh YJ \& Jung DS 2015 Evaluation of probiotic properties of Lactobacillus and Pediococcus strains isolated from Omegisool, a traditionally 
fermented millet alcoholic beverage in Korea. LWT - Food Science and Technology 63 437-444

Oliveira MN, Sodini I, Remeuf F, Tissier JP \& Corrieu G 2002 Manufacture of fermented lactic beverages containing probiotic cultures. Journal of Food Science 67 2336-2341

Oliveira MEG, Garcia EF, Egypto-Queiroga RDR \& Souza EL 2012 Technological, physicochemical and sensory characteristics of a Brazilian semi-hard goat cheese (coalho) with added probiotic lactic acid bacteria. Scientia Agricola 69 370-379

Oliveira MEG, Garcia EF, Oliveira CEV, Games AMP, Pintado MME, Madureira A, Conceição ML, Egypto-Queiroga RDR \& Souza EL 2014 Addition of probiotic bacteria in a semi-hard goat cheese (coalho): survival to simulated gastrointestinal conditions and inhibitory effect against pathogenic bacteria. Food Research International 64 241-247

Oliveira KAD, Ribeiro LS, Oliveira GV \& Vidigal M 2016 Goat milk frozen yogurt caja (Spondias mombin L.) flavor: development and sensory acceptance of an exotic food. Current Nutrition \& Food Science 12 105-112

Paula AT, Jeronymo-Ceneviva AB, Silva LF, Todorov SD, Franco B \& Penna ALB 2015 Leuconostoc mesenteroides SJRP55: a potential probiotic strain isolated from Brazilian water buffalo mozzarella cheese. Annals of Microbiology 65 899-910

Perin LM, Savo Sardaro ML, Nero LA, Neviani E \& Gatti M 2017 Bacterial ecology of artisanal Minas cheeses assessed by culture-dependent and -independent methods. Food Microbiology 65 160-169

Pimentel TC, Garcia S \& Prudencio SH 2012 Probiotic yoghurt with inulintype fructans of different degrees of polymerization: physicochemical and microbiological characteristics and storage stability. SeminaCiencias Agrarias 33 1059-1069

Pimentel TC, Garcia S \& Prudencio SH 2017 Produtos lácteos funcionais. In Produção, Processamento e Fiscalização de Leite e Derivados, Vol. 1, pp. 205-226 (Eds. LA Nero, AG Cruz \& LS Bersot). Atheneu: São Paulo, SP, Brazil

Reid G 2015 The growth potential for dairy probiotics. International Dairy Journal 49 16-22

Ribeiro EP, Simoes LG \& Jurkiewicz CH 2009 Development of Brazilian Minas soft cheese with Lactobacillus acidophilus produced with retentates obtained by ultrafiltration of milk. Ciencia e Tecnologia de Alimentos 29 19-23

Riboldi GP, de Mattos EP, Guedes Frazzon AP, d'Azevedo PA \& Frazzon J 2008 Phenotypic and genotypic heterogeneity of Enterococcus species isolated from food in Southern. Journal of Basic Microbiology 48 31-37

Salminen S, Ouwehand A, Benno Y \& Lee YK 1999 Probiotics: how should they be defined? Trends in Food Science \& Technology 10 107-110

Sanders ME 2008 Probiotics: definition, sources, selection, and uses. Clinical Infectious Diseases 46(Suppl. 2) S58-S61
Sant'Anna FM, Acurcio LB, Alvim LB, Castro RD, Oliveira LG, Silva AM, Nunes AC, Nicoli JR \& Souza MR 2017 Assessment of the probiotic potential of lactic acid bacteria isolated from Minas artisanal cheese produced in the Campo das Vertentes region, Brazil. International Journal of Dairy Technology 70 592-601

Santos KMO, Vieira ADS, Rocha CRC, Nascimento JCF, Lopes ACD, Bruno LM, Carvalho JDG, Franco BDGM \& Todorov SD 2014 Brazilian artisanal cheeses as a source of beneficial Enterococcus faecium strains: characterization of the bacteriocinogenic potential. Annals of Microbiology 64 1463-1471

Santos KMO, Vieira ADS, Buriti FCA, Nascimento JCF, Melo MES, Bruno LM, Borges MD, Rocha CRC, Lopes ACD, Franco BDGM \& Todorov SD 2015 Artisanal Coalho cheeses as source of beneficial Lactobacillus plantarum and Lactobacillus rhamnosus strains. Dairy Science \& Technology 95 209-230

Silva AS, Honjoya ER, Inay OM, Costa MD, Souza CHB, Santana EHW, Suguimoto HH \& Aragon-Alegro LC 2012 Viability of Lactobacillus casei in chocolate flan and its survival to simulated gastrointestinal conditions. Semina-Ciencias Agrarias 33 3163-3170

Tulini FL, Winkelstroter LK \& De Martinis ECP 2013 Identification and evaluation of the probiotic potential of Lactobacillus paraplantarum FT259, a bacteriocinogenic strain isolated from Brazilian semi-hard artisanal cheese. Anaerobe 22 57-63

Viegas RP, Souza MR, Figueiredo TC, Resende MFS, Penna C \& Cerqueira M 2010 Quality of functional fermented milks produced by the use of lactic acid bacteria isolated from coalho cheese. Arquivo Brasileiro de Medicina Veterinaria e Zootecnia 62 460-467

Vieira CP, Cabral CC, Lima B, Paschoalin VMF, Leandro KC \& Conte CA 2017 Lactococcus lactis ssp cremoris MRS47, a potential probiotic strain isolated from kefir grains, increases cis-9, trans-11-CLA and PUFA contents in fermented milk. Journal of Functional Foods $\mathbf{3 1}$ $172-178$

Weschenfelder S, Paim MP, Gerhardt C, Carvalho HHC \& Wiest JM 2018 Kefir: composition and evaluation of in situ antagonistic activity against Staphylococcus aureus and Escherichia coli. Revista Ciencia Agronomica 49 450-457

Zacharof MP \& Lovitt RW 2012 Bacteriocins produced by lactic acid bacteria: a review article. APCBEE Procedia 2 50-56

Zanirati DF, Abatemarco M, Sandes SHD, Nicoli JR, Nunes AC \& Neumann E 2015 Selection of lactic acid bacteria from Brazilian kefir grains for potential use as starter or probiotic cultures. Anaerobe 32 70-76

Zhang F, Jiang M, Wan C, Chen X, Chen X, Tao X, Shah NP \& Wei H 2016 Screening probiotic strains for safety: evaluation of virulence and antimicrobial susceptibility of enterococci from healthy Chinese infants. Journal of Dairy Science 99 4282-4290 